\title{
The Dynamics of Manpower Resources and Labor Value Criteria: Research Hypothesis Substantiation
}

\author{
Vadim Snegirev $^{1}$, Alena Borisova ${ }^{1 *}$ \\ ${ }^{1}$ Novosibirsk State Technical University, Russia \\ *Email: bborisova2012@yandex.ru
}

\begin{abstract}
The research question is formulated: the dynamics of manpower resources and value criteria to different generational groups labor. The research was conducted to reveal and differentiate generational groups' features, which influence the value system and criteria of labor. The measure of compliance between employees' criteria and conditions, provided by an employer, is determined. The poll's results of specialists $(\mathrm{N}=539)$, seeking a job in various companies' areas. Diagnostics tasks were the following: the applied tools for labor and personnel motivation; the adjustment rate of the applied tools for different generational groups; contradictions in value criteria and ways of their satisfaction inside companies. Significant quantitative non-coordination of labor market participant interests, including under-exploitation of professional potential, is recorded. The change of market participant value criteria for labor takes place. It is possible to study the criteria dynamics on the basis of the theory of individuals segmentation as per generational groups. The segmentation takes into account the influence of key events, occurred in the period of socialization and active personal development, which had an impact on professional system establishment.
\end{abstract}

Keywords: Stimulation tools, Manpower resources, Labor criteria, The theory of generational groups, Motivation differences.

\section{INTRODUCTION}

The net effect of factors affects the dynamics of employers' labor demand. Labor demand and its characteristics are actually the integral characteristic of the occurring changes and reflect the range frequency of economic demand for professionally skilled manpower parameters' set and conditions of collaborative engagement employer-employee. The qualitative constituent of manpower resources changes simultaneously with the modifications of market quantitative parameters. Professional and personal attributes and value criteria on employees' labor undergo changes. Parameters of employers' labor demands are also modified in a qualitative manner. The implementation of these changes requires the transformation of legal regulatory and infrastructural norms. Value systems are generally implemented by individuals, the establishment of labor demand undergoes evaluation and acceptance by the professional community. The dominant trends in society development shape the total of responsive impacts of professional communities. The manifestation of value criteria can be monitored through different processes, including sociallabor relationships between an employee and an employer.

The beginning of the 21 st century defines the shift of research interest vector to the theory of generational groups: the search of applicative knowledge begins - it's the back response of the impact tools. There appear researches (in various knowledge fields), where the theory of generational groups is used as the main instrument for the differentiation of the surveillance object - personnel. The differences in object attributes are taken as a basis, the impact of tools on overall resultants is being analyzed. Thus, in the base period, there is: «presentation and proof of the basic postulates of the theory to the professional community; the research of the evidence basis formation and various samples testing is conducted; the distribution of groups is formed as per the year of birth and society development factors, which are 
significantly manifested during the period of social and professional development of generation representatives; typical features, inherent in the representatives of each generation group, are identified and proved.

The shift in the approach to labor stimulation and instrument equipment of their implementation sets a research question about responsive reaction and readiness of companies' management to deal with other value criteria of specialists, to adapt motivation tools to employees target criteria.

Author's research hypothesis - about the existence of differences in intensity of response reactions of employees - representatives of various generational groups to the same set of corrective actions while the staffing process by the company.

These arguments and the proposed hypothesis determine the concept, the logic of the research, and the present article:

- we will consider which motivation and stimulation tools for the personnel are used by companies on personnel age change;

- we will determine the adjustment rate of the applied tools for different generational groups;

- we will discuss the non-coordination in value criteria and ways of their satisfaction inside companies.

In summary, we will make a conclusion as to changes in labor stimulation methods for different generation groups and particular characteristics of value criteria satisfaction, labor stimulation, applied practically during the personnel relations on the labor market.

\section{RESEARCH METHODOLOGY}

The questionnaire method of data-gathering was taken to identify the dynamics of approaches to the establishment of labor stimulation tools and changes in value criteria and motivation of specialists. Pilot questionnaire was fulfilled for this purpose. The research covered 539 respondents working in organizations engaged in various types of activities such as finance (JSC «VTB»), healthcare (Clinic №16, Novosibirsk), education (Novosibirsk State Technical University). trade («Magnit», «Pyaterochka», «Metro»), production $(\mathrm{JSC} \ll \mathrm{NZPP}, \mathrm{CJSC} \ll \mathrm{RES} »$, etc. $)$.

The questionnaire structure allows revealing the differences in labor value criteria for employers and employees. A considerable number of stimulation and impact tools, used in management theory, were taken into account when developing a questionnaire. $[1,2]$.

\section{RESEARCH RESULTS. TOOLS FOR PROVIDING SUPPORTABILITY AND STIMULATION OF MANPOWER RESOURCES}

The dynamics of the country's manpower resources availability shows an ageing tendency and a slow impact rate in providing regulatory events by manpower resources. The number of potentially high efficient resources between the ages of 25 to 39 has come to 1992 values. Herewith an estimated quarter of employed in the economy field is over 50 years of age [3].

The data analysis of employers' demand dynamics for manpower resources steadily trends upwards. Thus, significant quantitative non-coordination of labor market participant interests is recorded. For this reason, the calculation programs and grounds of predictive staff demand for the region are applied as regulatory measures [4]. Taking into account the limitations of the data on unemployment we will consider the structural content of the "unemployment rate" indicator.

In the range of unemployed people of the last few years a large share is taken by specialists of age groups of «20-24» $(18,5 \%, 2018,17,6 \%, 2019), \ll 25-29 »(16,0 \%$ $2018,2019)$, «30-34» $(13,6 \%, 2018,14,4 \%, 2019)$ [16].

The peak of working efficiency falls at this age, and employees are characterized by significant mobility in searching for better working conditions. The fact that almost half of the unemployed are in the active phase of the labor cycle indicates the non-coordination of demands and the continuing market formation. At the same time, the market adjustment rate is increasing: so the job search period and employment of every third person is up to 3 months, and every fifth finds work within 6 months. (an increase of 5\% in 2019 compared to 2018) [5]. Herewith the tendency towards the employer's preferences for hiring less aged employees remains: thus, the direct relationship between age and the job search period is recorded [6]. In general, this situation characterizes a weak adjustment rate of the market infrastructure to the tasks of the participants' criteria coordination.

Thus, the labor market is characterized by limited possibilities of manpower resources range; by irrational use of high efficient working personnel's potential, and, as a result, their high market mobility; by noncoordination of employers' and employees' demands, by low development and renovation rates of infrastructure facilities to assist the interest coordination growth.

The set of resulting criteria is not completed and we can assume the increasing number of researches on the basis of the analysis of the difference in perception by a person of input signals and responsive reactions to impacts. Information about the cause-and-effect link between impact stimulus and responsive reactions allows 
Table 1. Age distribution of generational groups

\begin{tabular}{|l|c|c|}
\hline \multicolumn{1}{|c|}{ Title and key } & Age at the present moment & Years of birth \\
\hline X & $36-56$ & $1983-1963$ \\
\hline early Y1 & $31-35$ & $1984-1988$ \\
\hline Y2 & $25-30$ & $1989-1994$ \\
\hline late Y3 & $16-24$ & $1995-2003$ \\
\hline Z & under 16 & 2003-2023 \\
\hline
\end{tabular}

Reference: written by the author.

estimating the efficiency of management decisions. Such links are also typical to staffing processes $[7,8]$. The differences of labor subjects - representatives of various generational groups are evident. Staffing characteristics differences and individual labor value criteria can be revealed and grounded by means of the summarized results of authors' research on the theory of generational groups.

For deeper differentiation and special examination of management tools' influence on personnel of various ages, the age range of generational groups is extended (table. 1.). There are groups that dominate now on the labor market: generations «late $Y$ » and «early $Z$ » actively integrate into a working process $[9,10]$.
A review of the dominant characteristics of employees - representatives of different generational groups was performed, and leading qualities and labor value criteria were segmented (table 2.).

The revealed differences and peculiarities of various generational groups' representatives influence individual labor value criteria. The changes in working behavior patterns of employees typical to personnel of various generational groups are recorded by specialists $[11,12,13]$. Representatives of $\mathrm{Y}$ and $\mathrm{Z}$ are characterized by a great diversity of active search patterns for selfrealization and shifting of focus demand. Thus, it is logical to assume that management impact tools on their performance should be changed [14,15].

Table 2. Main attributes and value criteria to the labor of different generational Groups representatives

\begin{tabular}{|c|c|c|c|c|c|}
\hline \multirow{2}{*}{$\begin{array}{l}\text { item } \\
\text { №. }\end{array}$} & \multirow[t]{2}{*}{ Group title } & \multirow{2}{*}{$\begin{array}{l}\text { Age at the } \\
\text { present } \\
\text { moment }\end{array}$} & \multirow{2}{*}{$\begin{array}{l}\text { Main personal and } \\
\text { professional attributes }\end{array}$} & \multicolumn{2}{|c|}{ Value criteria } \\
\hline & & & & to life & to labor \\
\hline 1 & $x$ & $36-56$ & $\begin{array}{l}\text { Hard-working nature, } \\
\text { responsibility, empathy, } \\
\text { dedication, connections, } \\
\text { respect }\end{array}$ & $\begin{array}{l}\text { Stability, prosperity, } \\
\text { longevity, confidence } \\
\text { and trust, self-sacrifice }\end{array}$ & $\begin{array}{l}\text { Responsibility, } \\
\text { courage, leadership, } \\
\text { stability, duty } \\
\text { performance nature }\end{array}$ \\
\hline 2 & early Y1 & $31-35$ & $\begin{array}{l}\text { Benefit, career, teamwork, } \\
\text { connections, optimism, } \\
\text { solicitude, dedication }\end{array}$ & $\begin{array}{l}\text { Family, trust, firmness, } \\
\text { fear, morality, idealism, } \\
\text { attitude }\end{array}$ & $\begin{array}{l}\text { Commitment, loyalty, } \\
\text { nepotism, ambitions, } \\
\text { anchor }\end{array}$ \\
\hline 3 & Y2 & $25-30$ & $\begin{array}{l}\text { Individualism, sociability, } \\
\text { vitality, courage, self- } \\
\text { sufficiency }\end{array}$ & $\begin{array}{l}\text { Capacity to plan, } \\
\text { flexibility, modification, } \\
\text { knowledge, duty } \\
\text { performance }\end{array}$ & $\begin{array}{l}\text { The right to vote, } \\
\text { leadership, } \\
\text { monetization, } \\
\text { teamwork }\end{array}$ \\
\hline 4 & late Y3 & $16-24$ & $\begin{array}{l}\text { Flexibility, motivation, } \\
\text { enthusiasm, dissension, self- } \\
\text { realization }\end{array}$ & $\begin{array}{l}\text { Luxury, fame, hope, } \\
\text { speed, energy }\end{array}$ & $\begin{array}{l}\text { Flexibility, option } \\
\text { right, dependence, } \\
\text { rudeness }\end{array}$ \\
\hline 5 & Z & under 16 & $\begin{array}{l}\text { Perfectionism, freethinking, } \\
\text { flexibility, digitalization, } \\
\text { activity }\end{array}$ & $\begin{array}{l}\text { Negligence, liberty, } \\
\text { courage, dreams, } \\
\text { expectations }\end{array}$ & $\begin{array}{l}\text { Greed, saving, } \\
\text { activity, flexibility, } \\
\text { merging }\end{array}$ \\
\hline
\end{tabular}

Reference: written by the author. 


\section{DISCUSSION OF RESULTS}

The results show that employers use a big range of stimulation tools for employees of various age groups from 16 to 35 years (figure 1). It may be determined by the following: a) an employer has to provide large diversity to keep highly mobile employees; b) testing of the influence of various impact measures is in progress on change of the market structure in terms of the generational aspect. There are no records as for significant frequency of extended stimulus set with other age groups.

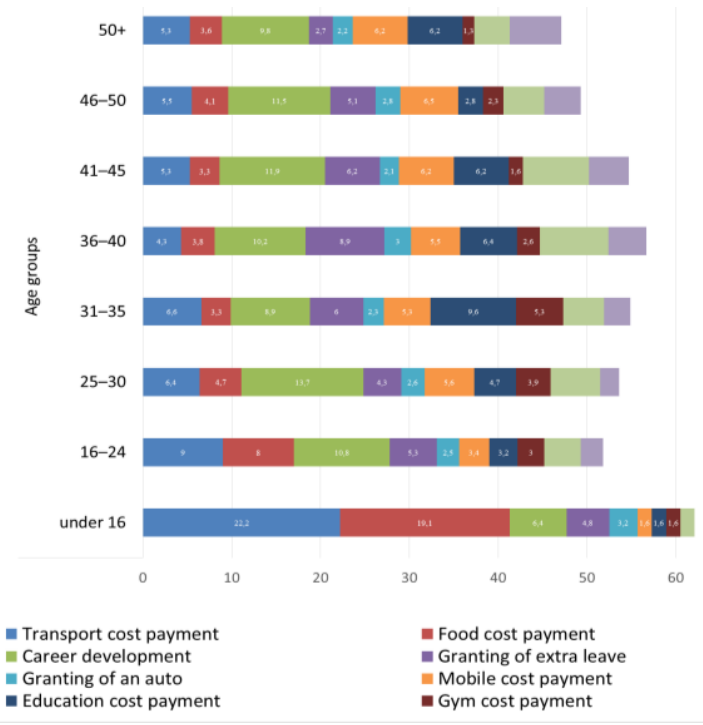

Figure 1 Stimulation tools used by an employer.

Reference: written by the author».

In the way of evidence of non-coordination between employers' actions and dominant labor criteria of various generation representatives, the comparison of the importance of stimulation for an employee and its actual implementation by an employer was conducted (figure 2).

The comparison of stimulus allowed making a series of conclusions:

- over $40 \%$ of «late $»$ is not satisfied by interaction modes with employers. This situation is much less common in other groups of respondents;

- the difference in wage satisfaction for all ages groups is significant. It can be most likely explained by high demands at the beginning of working career and low estimations of qualification level by employers, as well as the vulnerability of employees over 45 years of age on the market;

- employees from 30 to 40 years of age, who is physically capable of combining work and time spent on the road, have to work in places with inconvenient transport junction;

- management systems have not been yet established the implementation mechanism of demand satisfaction tools for generations $\mathrm{Y}$ and $\mathrm{Z}$, especially in terms of professional and career development (more than $50 \%$ of such respondents are not satisfied with this aspect);

- a large number of unsatisfied employees in each age group evidence that the applied approach to the working activity organization does not provide the balance in work and diverse-filled life.

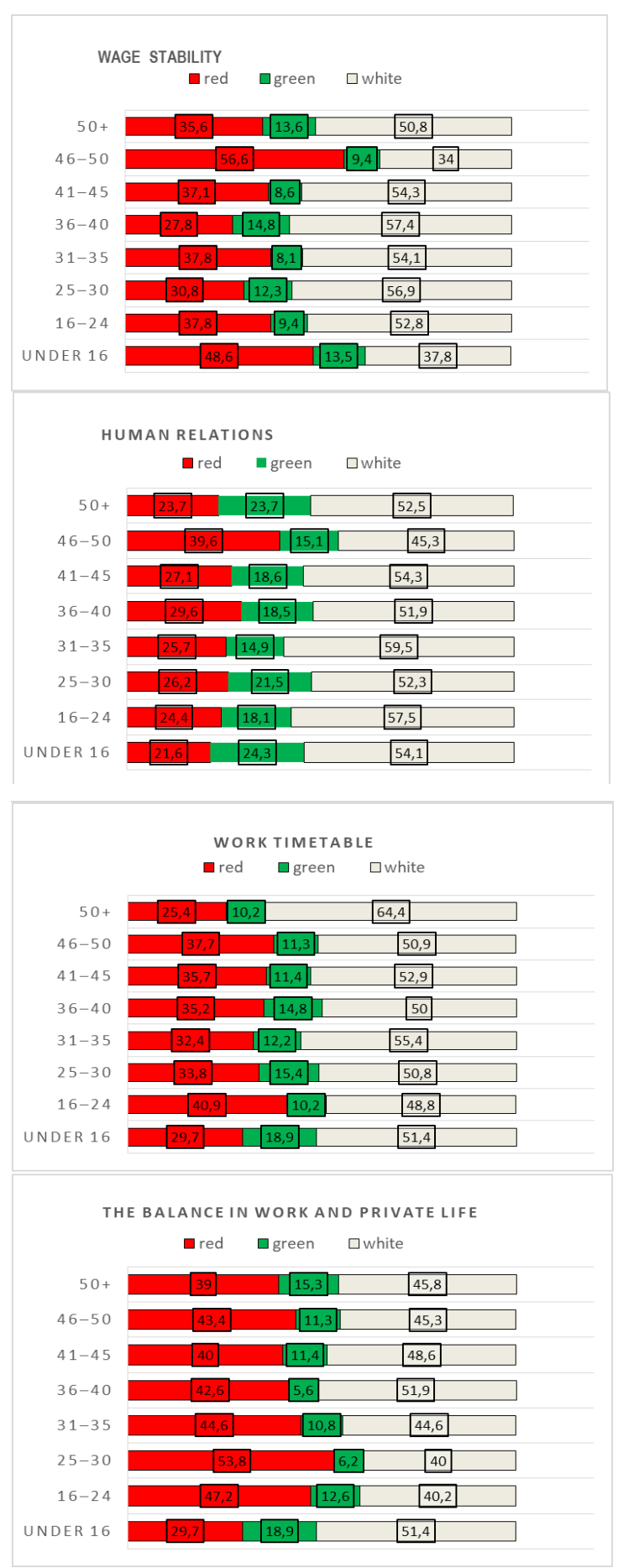

Figure 2 Coordination zones of employees' demands and conditions provided by employers, $\%$. 


\section{CONCLUSION}

In general, the confirmation of the following provisions have been received:

- the applied range of stimulus is standardized and is not adapted to the demands of various age groups;

- quite a slow adjustment of tools range is observed, especially for high-efficiency employees;

- non-coordination of value criteria and ways of their satisfaction inside a company increases the structural and content imbalance in the labor market.

The differentiation of management impact measures on employees of various ages can be observed. The hypothesis confirmation defines the new managerial task to identify the differences in the approaches of various age group employees working activity organization, and the necessity of a regular change of earlier applied organization tools, coordination, control, motivation and stimulation.

\section{REFERENCES}

1. V.R. Vesnin, Upravlenie personalom, Teoriya i praktika, [Staff management. Theory and Practice], M.: Prospect, 2007, 688 p.

2. I.M. Gurova, S.Sh. Evdokimova, Theory of generations as a tool for analysis, formation, and development of labor potential, MIR (Modernization. Innovations. Development) 3(27) (2016) 150-159. DOI: https://doi.org/10.18184/20794665.2016.7.3.150.15 $\underline{9}$

3. N.A. Zaytseva, Teoriya pokoleniy: my raznye ili odinakovye? [Theory of generations: are we same or different?], Russian regions: looking into the future 2 (2015) 220-236. Retrieved from: https://cyberleninka.ru/article/n/teoriya-pokoleniymy-raznye-ili-odinakovye

4. I.A. Ivanova, Theory of generations: the problems of learning and adaptation of young professionals in the 21st century, Transport business of Russia, 2016, pp. 103105.

5. N.V. Samoukina, Teoriya pokoleniy v rossiyskom menedgmente [Theory of generations in Russian management], M., RuScience, 2018, 185 p.

6. A.V. Sapa, Pokolenie Z - pokolenie epohi FGOS [Generation Z - generation of the FSES times], Innovative projects and programs in education 2 (2014) 24-30. Retrieved from: https://cyberleninka.ru/article/n/pokolenie-zpokolenie-epohi-fgos

7. Y.G. Odegov, A. Shklyaev, S. Kartashov, V. Lukashevich, Upravlenie chelovecheskimi resursami [Human resources management], M.: KnoRus, 2014, 222 p.

8. A.A. Rahimov, Socio-psychological interaction potential with youth in the education system through the theory of generations, Tupolevskie chteniya (shkola molodyh uchenyh) [Tupolev readings (school of young scientists)], 2017, pp. 647-651.

9. A.A. Borisova, I.V. Ryazantseva, V.A. Snegirev, Theoretical and applied research on regulation of social-labor relations using the theory of generations, Russian Journal of Labor economics Vol. 6 Iss. 2 (2019) 677-688.

10. V.A. Snegirev, Staffing: incentives and the impact on workers of different age groups, Russian Journal of Labor economics Vol. 7 No 4 (2020) 347-364.

11. J. Bejtkovsky, The Employees of Baby Boomers Generation, Generation $\mathrm{X}$, Generation $\mathrm{Y}$ and Generation $\mathrm{Z}$ in Selected Czech Corporations as Conceivers of Development and Competitiveness in their Corporation, Journal of competitive 4 (2016) 105-123.

12. F. Corbisiero, E. Ruspini, Millennials and Generation Z: Challenges and Future Perspectives for International Tourism, Journal of tourism futures 1 (2018) 3-6.

13. M. Cho, M. Bonn, Generation Z's Sustainable Volunteering: Motivations, Attitudes and Job Performance, Sustainability 520181400.

14. J.M. Pousson, K. Myers, Ignatian Pedagogy as a Frame for Universal Design in College: Meeting Learning Needs of Generation Z, Education sciences 4 (2018) 193.

15. E. Robak, Expectations of generation Y connected with shaping the work-life balance, The case of Poland, Oeconomia copernicana 4 (2017) 579-594.

16. News-magazine «Trud i zannyatost v Rossii» [Labour and employment in Russia] electronic resource. Retrieved from: https://rosstat.gov.ru/folder/210/document/13210 (accessed on 12.10.2020) 